\title{
Measuring the Efficiency of Turkish SMEs: A Data Envelopment Analysis Approach
}

\author{
Arzum Büyükkeklik ${ }^{1}$, Harun Dumlu ${ }^{2} \&$ Samet Evci ${ }^{3}$ \\ ${ }^{1}$ Departmant of International Trade and Logistics Management, Nigde University, Nigde, Turkey \\ ${ }^{2}$ Departmant of Business Administration, Nigde University, Nigde, Turkey \\ ${ }^{3}$ Departmant of International Trade and Logistics, Osmaniye Korkut Ata University, Osmaniye, Turkey \\ Correspondence: Arzum Büyükkeklik, Nigde University, Faculty of Economics and Administrative Sciences, \\ Nigde, 51240, Turkey. Tel: 90-388-225-2064. E-mail: abuyukkeklik@nigde.edu.tr
}

Received: February 29, 2016

Accepted: March 16, 2016

Online Published: May 25, 2016

doi:10.5539/ijef.v8n6p190

URL: http://dx.doi.org/10.5539/ijef.v8n6p190

\begin{abstract}
Small and medium-sized enterprises (SMEs) that are undertaking significant roles in the development of the economy of Turkey and in the increase of the production and employment encounter with many problems. Financial problems take an important place among them. The resources that could be used by SMEs in meeting the financing needs to be limited require the efficient use of these resources. In this study, the resource activities of SMEs have been studied with Data Envelopment Analysis (DEA). In analysis short-term liabilities, long-term liabilities and equity values of the enterprises that are quoted continuously on SME Industrial Index within 2011-2014 have been used as input variables; and the sales revenue and net profit values have been used as output variables. The total efficiency values of each decision making unit have been attained with the use of CCR model according to the years, technical efficiency values of them have been attained with the use of BCC model and the scale efficiency values of them have been attained by comparing these values to each other. As a result, it has been determined that those providing resource efficiency are only a few among the enterprises that are proceeded in the BIST SME Industrial Index; and these enterprises could reach their existent sales revenue and net profit numbers with less resources. In this respect it has been revealed that the SMEs that have problems in providing credit and not having strong equity structure are not able to make use of their own resources efficiently.
\end{abstract}

Keywords: efficiency measuring, DEA, BIST SMEs industrial index, Turkish SMEs

\section{Introduction}

Small and medium-sized enterprises (SMEs) are the economic items that help the increase of the economic and social welfare of the countries by contributing to the entrepreneurship, increase of employment and the decrease of the interregional development difference (Cook, 2001). SMEs defined by taking different scales as the basis by the countries are defined as small enterprises in the event that their number of staff is less than 50, as medium enterprises in the event that their number of staff is between 50-250 by the European Union (Prusa, 2012; Önüt \& Soner, 2007). In Turkey; it is defined as the economic units or entrepreneurships that employs less than 250 people annually and whose annual net sales revenue or any one of annual balance sheet does not exceed 40 million Turkish Lira (www.resmigazete.gov.tr). According to the data of Turkish Statistical Institute (TUIK); the SMEs in Turkey form as much as $99,8 \%$ of the enterprises conducting activities in industrial and service sectors in Turkey. In addition; these enterprises have a significant importance among the Turkish economy in that they form $75,8 \%$ of the employment, $54,5 \%$ of the salaries and prices, $63,3 \%$ of the turnover, $54,2 \%$ of the factor cost and added-value and $53,2 \%$ of the gross investment regarding financial goods (www.tuik.gov.tr).

Despite their serious contributions to the Turkish economy; SMEs have problems in many areas such as organization and management, supply, production management, marketing management, export, financial management, accounting management, human resources management, public relations, research and development $(\mathrm{R} \& \mathrm{D})$ and decision making (Akgemci, 2001). Financial problems have a significant importance among them. Turkish SMEs to be able to stay alive in the global market that has been shaped by the new economy and globalization and to be able to keep up in such a competitive environment is dependent on a rigid 
equity structure and strong financial bodies (Kutlu \& Demirci, 2007). However; the equities of the SMEs are insufficient and the alternative resources they could use in meeting the financing needs are limited. For this reason; the scarce resources should be used efficiently. Within this scope, efficiency measurement is important in terms of SMEs.

Efficiency connected to the utilization of resources and mainly effects the inputs of the productivity ratio (Tangen, 2005). Efficiency is a concept related to the aims and it determines the realization level of the aims by relating them to the results attained by the decision making unit (DMUs). Various methods are used in the measurement of efficiency such as ratio analysis, parametric and non-parametric solution methods. Ratio analysis is a method that is used more than other methods and that is easy to implement in the measurement of the financial efficiencies of DMUs. This method is applied with the proportion of one input and one output to each other. It is an important deficiency of the method to reach a decision by considering only a single ratio in the determination of the efficiencies of DMUs that cover lots of inputs and outputs. (Düzakın \& Düzakın, 2007). The parametric methods that is another method used in the measurement of efficiency has most frequently used three different models as the limit approach, free distribution approach and thick limit approach (Berger \& Humpery, 1997). Two important problems occur in the use of these methods (Tofallis, 2001). One of them is that there is no indication regarding how much the limit units are in convenience with the function; because, function only models the efficient units and it does not model the in efficient units. The second one of them is the fact that only a single output could be used in the parametric methods. This condition makes the use of these methods impossible for DMUs in which lots of inputs and outputs are used. The non-parametric methods do not take an analytical function as the basis in the measurement of efficiency and they measure the distance of the efficiency value attained with the use of linear programming based techniques to the efficiency limit (Keçek, 2010).

Widely-used one of the non-parametric methods is Data Envelopment Analysis (DEA). DEA having been developed by Charnes, Cooper, and Rhodes (1978) is a linear programming based method that is used to determine the relative efficiencies of DMUs in the event that there are lots of inputs and outputs and the outputs have different measurement units (Ramathan, 2003; Allen \& Thanassoulis, 2004). DEA is a "data-oriented" approach that produces more than one output by using more than one input and that is used to assess a series of performances of the similar entities called as DMUs (Cooper, Seiford, \& Zhu, 2004). DMUs are economic items that responsible for converting inputs to outputs. Inputs and outputs are selected after the determination of DMUs. While the inputs are the benefitted resources, outputs are the incomes and values that have been attained with the use of inputs. The third step of DEA is the determination of the most convenient DEA model for attaining the data and for the measurement of the relative efficiency.

The most important advantage of DEA method is the fact that it does not make any possible assumptions related to the structure of the production function (Reverte \& Guzman, 2010). At the beginning DEA that has been used to measure the efficiency of the non-profit corporations (Charnes, Cooper, \& Rhodes, 1981; Lewin \& Morey, 1981), afterwards has also been used in the measurement of the relative efficiencies of the profit making corporations conducting activities in different sectors (Chandara, Cooper, Li, \& Rahman, 1998; Drake \& Howcroft, 1994; Shammari, 1999; Zhu, 2000; Keh \& Chu, 2003; Düzakın \& Düzakın, 2007; Önüt \& Soner, 2007; Kao \& Hwang, 2008). DEA that is used in the conditions in which the inputs and outputs that are more than one and having different measurement units make conducting comparisons difficult is a method that provides opportunities for the determination of the inefficient resources of the inactive enterprises and that determines at what ratio developments are needed for these enterprises to be able to operate efficiently (Stokes, Tozer, \& Hyde, 2007). Within this scope; the method helps the decisions to be reached by the managers regarding the changes to be made in the input and output amounts for the provision of the efficiency.

In this study; it has been aimed to calculate and compare the efficiencies of the enterprises that are quoted continuously within 2011-2014 on Borsa Istanbul (BIST) SME Industrial Index according to their resource structures and to determine the improvements that should be carried out for the non-efficient enterprises. In the study; DEA out of the non-parametric methods has been used in the calculation of the efficiency. It is expected that the study shall provide benefits for the enterprises to determine at what ratio they use their resources efficiently and to determine the convenient resource amount to be able to attain the existent outputs. In addition; the study is different from the studies in the literature in that it takes the enterprises quoted on Turkey BIST SME Industrial Index as the subject, it uses the current data of the enterprises and discusses the resource efficiency of the enterprises. In the rest of this study; firstly the similar studies taking place in the literature have been summarized and after that, the study methodology has been explained and findings have been assessed. 


\section{Literature Review}

There are various studies measuring the efficiency of the SMEs in different countries in the literature (Table 1). Kotey and O'Donnell (2002) among them has examined the efficiency of SMEs in Australian food, alcoholic drinks and tobacco production industries with DEA. The findings of the study have shown that the family companies are less efficient when compared to other companies. Beck, Wigand, and König (2005) have analyzed the e-trade performance of the SMEs conducting activities in the production sector in Denmark, France, Germany and the USA on the basis of the information they have collected by means of questionnaire with the use of DEA. In the study, it has been concluded that the efficiency of Denmark and the USA in the issue of e-trade is better than that of France and Germany. Yang (2006) has analyzed the scale and technique activities of Korean SMEs within 2000-2002 regarding the production activities with DEA. Another study with the subject of Korean SMEs has been conducted by Lee (2013). In the study covering the years 2007-2012, the efficiency, effectiveness, growth and stability of the Korean shipyards with the qualification of SME have been examined with DEA. Numbers of the employees, capital and the operation age have been taken as input variables and the turnover and net profit items have been taken as the output variables. Findings have shown that except for some shipyards, the efficiency and effectiveness of most of the enterprises are not in the sufficient level and the growth and stability of the enterprises have been getting worse as of the global financial crisis.

Table 1. Literature review

\begin{tabular}{|c|c|c|c|c|}
\hline Studies & Countries & DEA Models & Input Variables & Output Variables \\
\hline $\begin{array}{l}\text { Beck, Wigand \& König, } \\
2005\end{array}$ & $\begin{array}{l}\text { Denmark, } \\
\text { France, } \\
\text { Germany \& } \\
\text { USA }\end{array}$ & CCR & $\begin{array}{l}\text {-Use of e-mail } \\
\text {-Public web site } \\
\text {-Use of intranet } \\
\text {-Use of extranet } \\
\text {-Use of EDI } \\
\text {-Use of electronic funds transfer } \\
\text {-Use of call center }\end{array}$ & $\begin{array}{l}\text {-Internal processe more efficient } \\
\text {-Staff productivity increasing } \\
\text {-Sales increased } \\
\text {-Sales area widended } \\
\text {-Customer service improved } \\
\text {-International sales increased } \\
\text {-Procurement costs decreased } \\
\text {-Inventory costs decreased } \\
\text {-Coordination suppliers improved } \\
\text {-Competitive position improved }\end{array}$ \\
\hline Kotey \& O’Donnell, 2002 & Australia & $\mathrm{BCC}$ & -Financial and operational data & -Financial and operational data \\
\hline Lee, 2013 & Korea & $\begin{array}{l}\text { CCR } \\
\mathrm{BCC}\end{array}$ & $\begin{array}{l}\text {-Number of labor units } \\
\text {-Capital } \\
\text {-Company age }\end{array}$ & $\begin{array}{l}\text {-Sales } \\
\text {-Net profits }\end{array}$ \\
\hline Prusa, 2012 & $\begin{array}{l}\text { Czech } \\
\text { Republic }\end{array}$ & $\mathrm{BCC}$ & $\begin{array}{l}\text {-Assets } \\
\text {-Investment } \\
\text {-Employees } \\
\text {-Wages } \\
\end{array}$ & $\begin{array}{l}\text {-Capital } \\
\text {-Labour } \\
\text {-Technology }\end{array}$ \\
\hline Reverte \& Guzman, 2010 & Spain & $\mathrm{BCC}$ & $\begin{array}{l}\text {-Cost of materials consumed } \\
\text {-Personnel expenses } \\
\text {-Depreciation expense } \\
\text {-Other operating expense }\end{array}$ & -Revenues \\
\hline Yang, 2006 & Korea & $\begin{array}{l}\mathrm{CCR} \\
\mathrm{BCC}\end{array}$ & $\begin{array}{l}\text {-Capital } \\
\text {-Labour } \\
\text {-Fixed Assets }\end{array}$ & $\begin{array}{l}\text {-Sales } \\
\text {-Operating profit } \\
\text {-Sum of finances } \\
\text {-Sum of other operating funds }\end{array}$ \\
\hline $\begin{array}{l}\text { Bayraktar, } \quad \text { Tatoglu } \quad \& \\
\text { Zaim, 2009 }\end{array}$ & $\begin{array}{l}\text { Turkey \& } \\
\text { Bulgaria }\end{array}$ & $\begin{array}{l}\mathrm{CCR} \\
\mathrm{BCC}\end{array}$ & $\begin{array}{l}\text {-Collaboration with suppliers } \\
\text {-Collaboration with customers } \\
\text {-Just in time supply } \\
\text {-E-supply } \\
\text {-Third party logistics } \\
\text {-Strategic planning } \\
\text {-Collaboration with suppliers }\end{array}$ & $\begin{array}{l}\text {-Short production time } \\
\text {-Demand forecasting } \\
\text {-The best resource planning } \\
\text {-Higher operational productivity } \\
\text {-Reduction of inventory levels } \\
\text {-Saving of cost } \\
\text {-Truer costing }\end{array}$ \\
\hline Gunay, 2015 & Turkey & $\mathrm{BCC}$ & $\begin{array}{l}\text {-Total assets } \\
\text {-Cost of sales }\end{array}$ & $\begin{array}{l}\text {-Net profits } \\
\text {-Sales proceeds }\end{array}$ \\
\hline Akın, 2010 & Turkey & CCR & $\begin{array}{l}\text {-Investment cost } \\
\text {-Maintenance and repair costs } \\
\text {-Personnel expenses } \\
\text {-Fixed expenses }\end{array}$ & $\begin{array}{l}\text {-Quantity of sales } \\
\text {-Turnover }\end{array}$ \\
\hline
\end{tabular}


Reverte and Guzman (2010) have measured the relative efficiency of the future-term profits to be attained by 1939 Spanish SMEs from the equity book cost and current incomes with DEA. In the study covering the years 1999-2004, incomes have been considered as output variables and the raw material incomes, personnel expenses, amortization expenses and other activity expenses have been considered as input variables. Findings of the study have shown that the implemented method is successful in the measurement of efficiency. Prusa (2012) has measured the economic efficiency of the Czech SMEs conducting activities in 30 different production sectors within 2002-2005. In the study in which DEA has been used, it has been revealed that most of the sectors are below complete efficiency and only a few sectors operate as fully efficient.

In the literature, there are also studies measuring the efficiency of SMEs conducting activities in Turkey with DEA. For instance, Bayraktar, Tatoğlu, and Zaim (2009) have compared the supply chain management application efficiencies of Turkish and Bulgarian SMEs via DEA. In the study, supply chain management applications have been used as input variables and operational performance criteria have been used as the output variables. The results have shown that the Turkish enterprises have efficiency values at a level that is better than those of the Bulgarian enterprises. Gunay (2015) has measured the efficiency of 10 food companies processed in BIST SME market with the use of the BCC model of input-oriented DEA. In the study; the total asset and the cost of the sales have been taken as the input variables and net profit and sales revenue values have been taken as output variables. The findings have revealed that 5 of the enterprises subjecting to the study are efficient. In addition, Akin (2010) has measured the relative efficiencies of 115 small enterprises conducting activities in the Western Mediterranean Region of Turkey with DEA. In the study; investment cost, maintenance and repair costs, personnel expenses and fixed expenses have been used as input variables and the sales amount and sales sum have been used as the output variables. It has been revealed that 22 enterprises conduct activities efficiently as a result of the analysis conducted according to the monthly sales amount and 4 companies conduct activities efficiently as a result of the analysis conducted according to the monthly sales sum.

\section{Materials and Methods}

\subsection{Research Method}

In the study; the relative efficiencies of the enterprises quoted on BIST SME Industrial Index have been measured with the use of input-oriented CCR and BCC models out of the DEA models. CCR model having been developed by Charnes, Cooper, and Rhodes (1978) is used in the event of fixed income according to the scale. BCC model has been developed by Banker, Charnes, and Cooper (1984) and it is a model that is used in the event of variable income according to the scale. While CCR measures the technical and scale efficiencies of DEAs, BCC measures the technical efficiencies of DEAs. Scale efficiency values are calculated by means of the proportion of the CCR values and BCC values to each other (Banker et al., 1984). These models could be input-oriented and output-oriented.

Input-oriented $\mathrm{CCR}$ and $\mathrm{BCC}$ models have been preferred in this study due to the fact that the resource efficiency of the enterprises is measured. Input-oriented CCR and BBC models realize a model solution that aims to decrease the input level to the minimum level after guaranteeing a certain output level. In a study that is based on CCR model, the efficiency value regarding each decision making unit is attained by making ratio of the weighted output to the weighted input maximum. The model is mathematically shown as follows (Charnes, Cooper, \& Rhodes, 1978):

$$
\max \mathrm{h}_{0}=\frac{\sum_{r=1}^{S} u_{r} y_{r 0}}{\sum_{i=1}^{m} v_{i} x_{i 0}}
$$

subject to:

$$
\begin{gathered}
\frac{\sum_{r=1}^{S} u_{r} y_{r j}}{\sum_{i=1}^{m} v_{i} x_{i j}} \leq 1 ; \quad j=1, \ldots . . \mathrm{n} \\
u_{r}, v_{i} \geq 0 ; \quad \mathrm{r}=1, \ldots \ldots . \mathrm{s} ; \quad \mathrm{i}=1, \ldots . . \mathrm{m}
\end{gathered}
$$

In the model, $\mathrm{y}_{\mathrm{rj}}$ and $\mathrm{x}_{\mathrm{ij}}$ symbolizes the output and input of $\mathrm{j}^{\text {th }}$ decision unit in sequence; and $\mathrm{u}_{\mathrm{r}}$ and $\mathrm{v}_{\mathrm{i}}$ symbolizes the weight of the related output and input in sequence. We have $n$ DMUs where each $\operatorname{DMU}_{j}(j=1, \ldots . n)$, produces the same $s$ outputs in different amounts, $y_{\mathrm{rj}}(\mathrm{r}=1, \ldots \mathrm{s})$, using the same $\mathrm{m}$ inputs, $\mathrm{x}_{\mathrm{ij}}(\mathrm{i}=1, \ldots \mathrm{m})$, also in different amounts. The efficiency of each decision unit is solved as follows with BCC (Banker, Charnes, \& Cooper, 1984; Banker, Cooper, Seiford, Thrall, \& Zhu, 2004):

$$
\min \theta_{0}-\varepsilon\left(\sum_{\mathrm{i}=1}^{\mathrm{m}} \mathrm{s}_{\mathrm{i}}^{-}+\sum_{\mathrm{r}=1}^{\mathrm{m}} \mathrm{s}_{\mathrm{r}}^{+}\right)
$$


Subject to;

$$
\begin{gathered}
\theta_{0} x_{i 0}=\sum_{\mathrm{j}=1}^{\mathrm{n}} \mathrm{x}_{\mathrm{ij}} \lambda_{\mathrm{j}}+\mathrm{s}_{\mathrm{i}}^{-}, \quad \mathrm{i}=1,2, \ldots, \mathrm{m}, \\
\mathrm{y}_{\mathrm{r} 0}=\sum_{\mathrm{j}=1}^{\mathrm{n}} \mathrm{y}_{\mathrm{rj}} \lambda_{\mathrm{j}}-\mathrm{s}_{\mathrm{i}}^{+}, \quad \mathrm{r}=1,2, \ldots, \mathrm{s}, \\
1=\sum_{\mathrm{j}=1}^{\mathrm{n}} \lambda_{\mathrm{j}}, \\
0 \leq \lambda_{j}, s_{i}^{-}, s_{r}^{+} \quad \forall i, r, j .
\end{gathered}
$$

3.2 Data

In this study; 17 enterprises quoted continuously on BIST SME Industrial Index in 2011, 2012, 2013 and 2014 and whose data could be reached have been selected as DMUs. The enterprises and their codes used in the analysis are given in Table 2.

Table 2. DMUs and codes and business sectors of DMUs

\begin{tabular}{lll}
\hline CODE & DECISION MAKING UNITS (DMUs) & Business Sectors \\
\hline DMU1 & A.V.O.D. Inc. & Food Industry \\
DMU2 & Berkosan Inc. & Isolation \& Insulation \\
DMU3 & Bilici Yatırım Inc. & Agriculture \& Textile \\
DMU4 & Birlik Mensucat Inc. & Textile \\
DMU5 & Burcelik Inc. & Steel Casting \\
DMU6 & Burcelik Valve Inc. & Steel Casting \\
DMU7 & Dogusan Inc. & Construction \\
DMU8 & Ersu Inc. & FoodIndustry \\
DMU9 & Federal-Mogul Inc. & Automotive Supply Industry \\
DMU10 & Ihlas Madencilik Inc. & Mining \\
DMU11 & Lüks Kadife Inc. & Textile \\
DMU12 & Matas Inc. & Typography \\
DMU13 & Nigbas Inc. & Construction \\
DMU14 & Sonmez Pamuklu Inc. & Tourism, Retail, Energy, Technology \& Construction \\
DMU15 & Taraf Inc. & Journalism \\
DMU16 & Vanet Inc. & Food Industry \\
DMU17 & Yaprak Sut Inc. & Food Industry \\
\hline
\end{tabular}

Note. "Matas Inc." title has changed as "Aksel Energy Inc." to be valid from the date of 11.01.2013 (www.kap.gov.tr).

It is necessary to be able to measure the efficiency of DMUs that the input and output variables belonging to these units should be detected and the selected input and output elements should be used for each decision unit. Based on the conducted literature review and the structure of the study; it has been decided that (1) short term liabilities, (2) long term liabilities and (3) equities shall be used as the input variables of the analysis. (1) sales revenue and (2) net profits of the companies have been used as the output variables. These data have been drawn from the balance sheet and income table belonging to the enterprises.

It is necessary that the restriction of the positivity of the variables is necessary to be able to calculate the efficiencies via input-oriented CCR and BCC models. As a result, the net profit items of all the enterprises subjecting to the study have been increased as much as the highest loss sum for the purpose of correcting the negative net profit items taking place within the output variable. On the other hand, it is also necessary that the number of the DMUs should be at least 1 more than that of the input and output or it should be twice as much as the total of the input and output number (Boussofianee, Dyson \& Rhodes, 1991). According to this; when the DMUs number subjecting to the study and the input-output number are compared to each other $(3+2+1<17$, $2 *(3+2)<17)$; it is seen that it is in accordance with DEA. 


\section{Empirical Results}

Following the conducted DEA analyses; the calculated efficiency values belonging to the companies are seen in Table 3 according to years. It could be said that the enterprises whose efficiency value has been calculated as 1 are efficient and those calculated below 1 are not efficient. According to the values taking place in Table 3; it is seen that 5 DMUs in 2011, 4 DMUs in 2012 and 2013 and 5 DMUs in 2014 have been efficient in the efficiency values calculated via CCR model; in other words, in the technical and scale efficiency values. Out of them; while DMU6 and DMU9 coded DMUs have been efficient in 4 years each, DMU7 has been efficient in 2011 and 2012, but it has lost its efficiency in 2013 and 2014. It has lost its efficiency degree to 0,174 especially in 2014. While DMU5 has not been efficient in 2011, it has increased its efficiency in 2012 and has become efficient. In the following years as 2013 and 2014; it has sustained its efficiency. It is seen that DMU8 has become efficient in 2011, but it has decreased its efficiency in the following years and has become inefficient. In addition; while DMU1 and DMU2 DMUs have not been efficient in the first three years, they have increased their efficiency values in 2014 and has succeeded to be efficient. It is seen that DMU3, DMU4, DMU10, DMU11, DMU13, DMU14, DMU15, DMU16 and DMU17 DMUs have not been efficient in all four years. In general meaning, the average efficiency values of the enterprises are at the levels around $60 \%$ for each year and it is seen that changes occur although they are on a yearly-basis.

Table 3. Efficiency values by years

\begin{tabular}{|c|c|c|c|c|c|c|c|c|c|c|c|c|}
\hline YEAR & & 2011 & & & 2012 & & & 2013 & & & 2014 & \\
\hline DMU & CCR & BCC & SE & CCR & BCC & SE & CCR & BCC & SE & CCR & BCC & SE \\
\hline DMU1 & 0,504 & 0,555 & 0,908 & 0,490 & 0,491 & 0,998 & 0,437 & 0,507 & 0,863 & 1 & 1 & 1 \\
\hline DMU2 & 0,604 & 0,606 & 0,997 & 0,574 & 0,575 & 0,998 & 0,587 & 0,630 & 0,932 & 1 & 1 & 1 \\
\hline DMU3 & 0,300 & 0,307 & 0,979 & 0,412 & 0,421 & 0,978 & 0,252 & 0,262 & 0,961 & 0,479 & 1 & 0,479 \\
\hline DMU4 & 0,654 & 0,668 & 0,978 & 0,989 & 0,992 & 0,997 & 0,851 & 1 & 0,851 & 0,041 & 0,409 & 0,099 \\
\hline DMU5 & 0,895 & 0,995 & 0,900 & 1 & 1 & 1 & 1 & 1 & 1 & 1 & 1 & 1 \\
\hline DMU6 & 1 & 1 & 1 & 1 & 1 & 1 & 1 & 1 & 1 & 1 & 1 & 1 \\
\hline DMU7 & 1 & 1 & 1 & 1 & 1 & 1 & 0,707 & 1 & 0,707 & 0,174 & 0,704 & 0,247 \\
\hline DMU8 & 1 & 1 & 1 & 0,467 & 0,473 & 0,989 & 0,831 & 0,836 & 0,993 & 0,256 & 0,537 & 0,477 \\
\hline DMU9 & 1 & 1 & 1 & 1 & 1 & 1 & 1 & 1 & 1 & 1 & 1 & 1 \\
\hline DMU10 & 0,226 & 0,250 & 0,907 & 0,252 & 0,401 & 0,629 & 0,581 & 1 & 0,581 & 0,413 & 0,872 & 0,474 \\
\hline DMU11 & 0,320 & 0,358 & 0,893 & 0,234 & 0,268 & 0,873 & 0,278 & 0,301 & 0,924 & 0,337 & 0,338 & 0,997 \\
\hline DMU12 & 1 & 1 & 1 & 0,946 & 1 & 0,946 & 1 & 1 & 1 & 0,939 & 1 & 0,936 \\
\hline DMU13 & 0,562 & 0,569 & 0,987 & 0,493 & 0,495 & 0,998 & 0,502 & 0,545 & 0,921 & 0,551 & 0,577 & 0,955 \\
\hline DMU14 & 0,266 & 0,327 & 0,813 & 0,337 & 0,438 & 0,770 & 0,762 & 0,990 & 0,770 & 0,936 & 1 & 0,939 \\
\hline DMU15 & 0,643 & 0,719 & 0,894 & 0,773 & 0,774 & 0,999 & 0,599 & 0,677 & 0,884 & 0,891 & 0,967 & 0,921 \\
\hline DMU16 & 0,183 & 0,359 & 0,509 & 0,231 & 0,561 & 0,413 & 0,187 & 0,514 & 0,364 & 0,339 & 0,384 & 0,883 \\
\hline DMU17 & 0,553 & 0,567 & 0,975 & 0,742 & 0,782 & 0,949 & 0,642 & 0,801 & 0,802 & 0,434 & 0,695 & 0,625 \\
\hline ME & $\mathbf{0 , 6 3 0}$ & 0,664 & $\mathbf{0 , 9 2 6}$ & 0,644 & 0,686 & 0,914 & 0,660 & 0,768 & 0,856 & 0,635 & 0,793 & 0,767 \\
\hline NED & 5 & 5 & 5 & 4 & 5 & 4 & 4 & 7 & 4 & 5 & 8 & 5 \\
\hline
\end{tabular}

SE: Scale Efficiency, ME: Mean Efficiency, NED: Number of Efficient DMUs.

When BBC values in Table 3 are examined; it is seen that 5 DMUs in 2011 and 2012, 7 DMUs in 2013 and 8 DMUs in 2014 have been efficient. DMU6 and DMU9 coded DMUs have been efficient in four years each also in BCC model as it has been in the efficiency results of the CCR model. DMU12 is efficient in all four years only according to BCC model. DMU5 not being efficient in 2011 has become efficient in 2012 and it has protected this efficiency in the following years. DMU3 and DMU14 coded DMUs having too low efficiency levels in 2011, 2012 and 2013 have been observed to have increased their efficiency values and have become efficient. It is seen that DMU4 and DMU10 coded DMUs have not been efficient except for 2013. In addition; while DMU1 and DMU2 coded DMUs have not been efficient in the first three years as it has been in CCR model, they have increased their efficiency values in 2014 and have succeeded to be efficient. When the efficiency values of DMU13, DMU15, DMU16 and DMU17 coded DMUs are considered, it is seen that they have not been efficient in all four years as it has been in CCR model. It could be expressed that there have been an increase in the average efficiency values occurring as a result of this model according to the years and while this level has been $66 \%$ in 2011 it has increased to $79 \%$ in 2014. Within this scope; it has been observed that 
DMUs have increased their technical efficiencies as much a $13 \%$ on average within years according to the BCC model.

On the other hand; according to the scale efficiency values taking place in Table 3, 5 DMUs in 2011, 4 DMUs in 2012 and 2013 and 5 DMUs in 2014 have had scale efficiency. A DMU should both have a total and scale efficiency to be able to have scale efficiency. When this situation is taken into consideration; it is seen in Table 3 that the DMUs whose both total efficiencies (CCR values) and technical efficiencies (BCC values) are 1 also have scale efficiency. According to the values of CCR and BCC models, DMU6 and DMU9 DMUs that have been efficient in all four years have scale efficiency in all the years. Again according to CCR and BCC models, it is seen in the table that DMU1 and DMU2 DMUs that could be efficient in only 2014 have scale efficiency only in this year and they do not have scale efficiency due to the fact that they have not been totally and technically efficient in the previous years. It is observed that DMU7 has had scale efficiency in 2011 and 2012, DMU12 has had scale efficiency in 2011 and 2013 and DMU8 has had scale efficiency only in 2011. Moreover; the fact that DMU3, DMU4, DMU10, DMU11, DMU13, DMU14, DMU15, DMU16 and DMU17 coded DMUs have not had scale efficiency in any year is another result deduced from the table. Furthermore; the average scale efficiency value has decreased according to years. While this value has been $92 \%$ in 2011 , it has decreased to $76 \%$ in 2014.

Which DMUs should be taken as reference by the DMUs that are inefficient according to years to be able to be efficient and the frequencies of these enterprises to be the references are given in Table 4. For instance; according to CCR model, if DMU1 coded DMU had taken DMU6 as reference, it would have reached technical and scale efficiency in 2012. In 2012; if it had taken DMU1 and DMU9 coded enterprises as references, it would have been efficient both according to CCR and BCC model and therefore, it would also be able to have scale efficiency. Because DMU1 coded enterprise has been efficient in 2014, there is no need for it to take any DMUs as reference.

Table 4. Reference DMUs by years and the reference numbers of DMUs

\begin{tabular}{|c|c|c|c|c|c|c|c|c|c|}
\hline \multirow{2}{*}{$\begin{array}{l}\text { YEARS } \\
\text { DMUs }\end{array}$} & \multicolumn{2}{|c|}{2011} & \multicolumn{2}{|c|}{2012} & \multicolumn{2}{|c|}{2013} & \multicolumn{2}{|c|}{2014} & \multirow{2}{*}{ Total } \\
\hline & CCR & BCC & CCR & BCC & CCR & BCC & CCR & BCC & \\
\hline DMU1 & DMU6 & DMU9 & DMU9 & DMU9 & DMU12 & DMU9 & - & - & - \\
\hline DMU2 & DMU6 & DMU6 & DMU6 & DMU6 & DMU12 & DMU12 & - & - & 1 \\
\hline DMU3 & DMU9 & DMU9 & DMU9 & DMU9 & DMU9 & DMU9 & DMU6 & - & - \\
\hline DMU4 & DMU8 & DMU8 & DMU9 & DMU6 & DMU9 & - & DMU6 & DMU12 & - \\
\hline DMU5 & DMU8 & DMU8 & - & - & - & - & - & - & - \\
\hline DMU6 & - & - & - & - & - & - & - & - & 21 \\
\hline DMU7 & - & - & - & - & DMU9 & - & DMU9 & DMU12 & 6 \\
\hline DMU8 & - & - & DMU9 & DMU9 & DMU9 & DMU9 & DMU9 & DMU12 & 6 \\
\hline DMU9 & - & - & - & - & - & - & - & - & 45 \\
\hline DMU10 & DMU7 & DMU7 & DMU9 & DMU9 & DMU9 & - & DMU9 & DMU12 & - \\
\hline DMU11 & DMU6 & DMU6 & DMU9 & DMU9 & DMU9 & DMU 6 & DMU6 & DMU9 & - \\
\hline DMU12 & - & - & DMU9 & - & - & - & DMU9 & - & 14 \\
\hline DMU13 & DMU8 & DMU8 & DMU9 & DMU9 & DMU12 & DMU9 & DMU9 & DMU2 & - \\
\hline DMU14 & DMU9 & DMU9 & DMU9 & DMU9 & DMU9 & DMU9 & DMU9 & - & - \\
\hline DMU15 & DMU6 & DMU6 & DMU6 & DMU6 & DMU12 & DMU12 & DMU6 & DMU6 & - \\
\hline DMU16 & DMU7 & DMU7 & DMU6 & DMU12 & DMU9 & DMU7 & DMU9 & DMU12 & - \\
\hline DMU17 & DMU6 & DMU6 & DMU9 & DMU12 & DMU9 & DMU7 & DMU9 & DMU12 & - \\
\hline
\end{tabular}

In addition, DMU9 coded DMU has become the enterprise which has been taken as reference as the most with the frequency of 45 times in total between 2012 and 2013 according to Table 4. This enterprise is followed respectively by DMU6 with the reference frequency of 21 times, DMU14 with the reference frequency of 14 times, DMU7 and DMU8 with the reference frequency of 6 times and DMU2 with the reference frequency of only once.

Because the efficiency values have been calculated under the assumption of fixed and variable income according to input-oriented scale in the study, what the minimum input amount should be for an output at a certain ratio has been determined. Within this scope; at what ratio the inefficient enterprises should have a decrease in their inputs, namely resources in 2014 to be able to be efficient has been calculated and given in Table 5 . 
Table 5. Potential improvement rates for inefficient DMUs (2014)

\begin{tabular}{lcccccc}
\hline \% & & CCR & & & BCC \\
\hline DMUs & STL & LTL & EQ & STL & LTL & EQ \\
\hline DMU1 & - & - & - & - & - & - \\
DMU2 & - & - & - & - & - & - \\
DMU3 & $-52,1$ & $-11,1$ & $-52,2$ & - & - & - \\
DMU4 & -96 & $-2,75$ & $-95,8$ & $-59,1$ & $-32,2$ & $-59,1$ \\
DMU5 & - & - & - & - & - & - \\
DMU6 & - & - & - & - & - & - \\
DMU7 & $-2,25$ & $-82,3$ & $-82,5$ & $-29,6$ & $-43,9$ & $-29,5$ \\
DMU8 & $-74,3$ & $-20,9$ & $-74,3$ & $-46,2$ & $-49,2$ & $-13,3$ \\
DMU9 & - & - & - & - & - & - \\
DMU10 & $-58,6$ & $-26,9$ & $-24,5$ & $-12,3$ & $-37,7$ & $-63,2$ \\
DMU11 & $-66,2$ & -24 & $-66,2$ & $-66,2$ & $-26,9$ & $-66,1$ \\
DMU12 & $-33,4$ & $-6,4$ & $-6,5$ & - & - & - \\
DMU13 & $-8,4$ & $-44,9$ & $-44,9$ & $-4,1$ & $-42,3$ & $-42,2$ \\
DMU14 & $-6,1$ & $-36,7$ & $-63,8$ & - & - & - \\
DMU15 & -20 & $-10,9$ & -11 & $-39,6$ & $-15,5$ & $-3,3$ \\
DMU16 & $-4,5$ & -66 & $-66,1$ & $-61,6$ & $-25,9$ & $-61,5$ \\
DMU17 & $-56,5$ & $-8,6$ & $-56,6$ & $-30,5$ & $-53,7$ & $-6,9$ \\
\hline
\end{tabular}

STL: Short Term Liabilities, LTL: Long Term Liabilities, EQ: Equity.

According to Table 5, it is seen that there is no need for DMU1, DMU2, DMU5, DMU6 and DMU9 coded DMUs that are efficient according to both CCR and BCC models in 2014 to conduct any enhancement. According to CCR model in 2014; DMU4 having the lowest efficiency value with 0,041 shall be able to be efficient just like DMU6 it has taken as reference in the event that it decreases STL value at the ratio of 96\%, LTL value at the ratio of 2,75\% and EQ value at the ratio of 95,8\%. DMU7 having the second lowest efficiency value with 0,174 should decrease its STL value at the ratio of 2,25\%, LTL value at the ratio of $82,3 \%$ and EQ value at the ratio of $82,5 \%$ to be able to be efficient. In addition; DMU12 having the highest efficiency value with 0,939 among the inefficient DMUs according to CCR model in 2014 shall be able to be efficient just like DMU9 it has taken as reference in the event that it decreases its STL value at the ratio of 33,4\%, LTL value at the ratio of $6,4 \%$ and EQ value at the ratio of $6,5 \%$.

When BCC values in 2014 are taken into consideration, DMU11 has the lowest efficiency level. This DMUs should decrease its STL value at the ratio of $66,2 \%$, LTL value at the ratio of $26,9 \%$ and EQ value at the ratio of $66,1 \%$ to be able to be efficient. DMU of DMU15 coded DMU having the highest efficiency value with 0,939 among the inefficient DMUs according to BCC model in 2014 shall be able to be efficient in the event that it decreases its STL value at the ratio of 39,6\%, LTL value at the ratio of 15,5\% and EQ value at the ratio of 3,3\%.

When the efficiency values and improvement ratios are taken into consideration, it is seen that DMUs having the lowest efficiency level need the highest improvement ratios as expected and DMUs having higher efficiency values need lower improvement ratios as expected again. Within this scope; the enterprises that shall carry out improvements in the input values according to the improvement ratios given in Table 4 shall be able to be efficient just like the enterprises they have taken as reference.

\section{Conclusion}

SMEs in Turkish economy are more than $99 \%$ of all enterprises. Within this scope, efficient usage of the scarce resources by SMEs has a critical importance in terms of the economy of the country, survival in the market for these enterprises and adaptation to the competitive environment. With this study; the resource efficiency of 17 enterprise quoted continuously on 2011, 2012, 2013 and 2014 in BIST SME Industrial Index has been examined with DEA models based on input-oriented CCR and BCC models. In addition; the improvements that should be carried out by non-efficient DMUs in short term liabilities, long term liabilities and equity items in 2014 have been covered.

Findings of the study showed that 5 DMUs in 2011, 4 DMUs in 2012 and 2013 and 5 DMUs in 2014 have conducted activities efficiently according to CCR model. According to BCC model, 5 DMUs in 2011 and 2012, 7 DMUs in 20138 DMUs in 2014 have conducted activities efficiently. Furthermore; 5 DMUs in 2011, 4 DMUs 
in 2012 and 2013 and 6 DMUs in 2014 have had scale efficiency. Among DMUs; DMU6 coded Burcelik Vana and DMU9 coded Federal-Mogul have become efficient both according to CCR and BCC models. Moreover; Burcelik Vana has been shown as reference 21 times and Mogul has been shown as reference 45 times and they have become the DMUs that should be taken as reference mostly. As a result of the study; it has been determined that inefficient enterprises in 2014 shall make contribution in the event that they decrease their inputs as much as $38 \%$ on average.

When taken into consideration in general meaning; there are only a few enterprises providing resource efficiency among those quoted on BIST SME Industrial Index. In addition; findings of the study reveal that these enterprises could reach the current sales revenue and net profit figures with fewer resources. This situation also reveals that SMEs having problems in the provision of credit and not having a strong equity structure are not able to make efficient use of the existent resources. Suggestions such as concentrating more on the financial management, searching for new financing techniques and methods and employing the people that are experts in this subject should be made to SMEs regarding the provision of resource efficiency and the solution of financing problems experienced.

\section{References}

Akgemci, T. (2001). Fundamental Problems of SMEs and Provided Supports for Them. Republic of Turkey Ministry of Science, Industry and Technology, Ankara: KOSGEB. Retrieved from http://www.kobider.org.tr/pdf/kobi_sorunlar_destekler.pdf

Akın, O. (2010). Evaluating the Comparative Productivities of the Bakeries by Using the Data Envelopment Analysis: A research in West Mediterranean Region. Journal of Academic Researches and Studies, 2(2), 89-106. Retrieved from http://iibfaacd.kilis.edu.tr/article/view/1094000015/1094000014

Allen, R., \& Thanassoulis, E. (2004). Improving Envelopment in Data Envelopment Analysis. Europen Journal of Operational Research, 154(2), 363-379. http://dx.doi.org/10.1016/S0377-2217(03)00175-9

Banker, R. D., Charnes, A., \& Cooper, W. W. (1984). Some Models for Estimating Thecnical and Scale Inefficiencies in Data Envelopment Analysis. Management Sciences, 30(9), 1078-1092. http://dx.doi.org/10.1287/mnsc.30.9.1078

Banker, R. D., Cooper, W. W., Seiford, L. M., Thrall, R. M., \& Zhu, J. (2004). Returns to Scale in Different DEA Models. Europen Journal of Operational Research, 154(2), 345-362. http://dx.doi.org/10.1016S0377/-1934(03)00174-7

Bayraktar, E., Tatoğlu, E., \& Zaim, S. (2009). A Relative Efficiency Comparison of Supply Chain Management Practices: A Study of Turkish and Bulgarian SMEs. ODTÜ Gelişme Dergisi, 36(2), 271-289. Retrieved from http://kutuphane.dogus.edu.tr/mvt/pdf.php

Beck, R., Wigand, R. T., \& König, W. (2005). Integration of E-Commerce by SMEs in the Manifacturing Sector: A Data Envelopment Analysis Approach. Journal of Global Information Management, 13(3), 20-32. http://dx.doi.org/10.4018/jgim.2005070102

Berger, A. N., \& Humphery, D. B. (1997). Efficiency of Financial Institutions: International Survey and Directions for Future Research. European Journal of Operational Research, 98(2), 175-212. http://dx.doi.org/10.1016/S0377-2217(96)00342-6

Boussofianee, A., Dyson, R., \& Rhodes, E. (1991). Applied Data Envelopment Analysis. European Journal of Operational Research, 52(1), 1-15. http://dx.doi.org/10.1016/0377-2217(91)90331-O

Chandara, P., Cooper, W. W., \& Li, S. (1998). Using DEA To Evaluate 29 Canadian Textile Companies Considering Returns to Scale. International Journal of Production Economics, 54(2), 129-141. http://dx.doi.org/10.1016/S0925-5273(97)00135-7

Charnes, A., Cooper, W. W., \& Rhodes, E. (1978). Measuring the Efficiency of Decision Making Units. European Journal of Operational Research, 2(6), 429-444. http://dx.doi.org/10.1016/0377-2217(78)90138-8

Charnes, A., Cooper, W. W., \& Rhodes, E. (1981). Evaluating Program and Managerial Efficiency: An Application of Data Envelopment Analysis to Program Follow Through. Management Science, 27(6), 668-697. http://dx.doi.org/10.1287/mnsc.27.6.668

Cook, P. (2001). Finance and Small and Medium-Sized Enterprise in Developing Countries. Journal of Developmental Entrepreneurship, 6(1), 17-40. 
Cooper, W. W., Seiford, L. M., \& Zhu, J. (2004). Handbook on Data Envelopment Analysis. Boston: Kluwer Academic Publishers.

Drake, L., \& Howcroft, B. (1994). Relative Efficiency in the Branch Network of a UK Bank: An Empirical Study. OMEGA, 22(1), 83-90. http://dx.doi.org/10.1016/0305-0483(94)90009-4

Duzakin, E., \& Duzakin, H. (2007). Measuring the Performance of Manufacturing Firms With Super Slacks Based Model of Data Envelopment Analysis: An Application of 500 Major Industrial Enterprises in Turkey. European Journal of Operation Research, 182(3), 1412-1432. http://dx.doi.org/10.1016/j.ejor.2006.09.036

Günay, B. (2015). Measuring BIST at Quoted SME of Food Companies with Data Envelopment Analysis. Akademik Bakıs Dergisi, 47, 16-30. Retrieved from http://www.akademikbakis.org/dergi//pdf

Kao, C., \& Hwang, S. (2008). Efficiency Decomposition in Two-Stage Data Envelopment Analysis: An application to Non-Life İnsurance Companies in Taiwan. European Journal of Operation Research, 185(1), 418-429. http://dx.doi.org/10.1016/j.ejor.2006.11.041

Keçek, G. (2010). Data Envelopment Analysis: Theory and Applications. Ankara: Siyasal Kitabevi.

Keh, H. T., \& Chu, S. (2003). Retail Productivity and Scale Economics at the Firm Level: A DEA Approach. OMEGA. International Journal of Management Science, 31(2), 75-82. http://dx.doi.org/10.1016/S0305-0483(02)00097-X

Kotey, B., \& O'Donnell, C. J. (2002). Data Envelopment Analysis in Small and Medium Enterprises: A Study of the Australian Food, Beverages and Tobacco Manufacturing Industry. Small Enterprise Research, 10(2), 3-22. http://dx.doi.org/10.5172/ser.10.2.3

Kutlu, H., \& Demirci, N. (2007). Financial Problems of SMEs and Solution Proposals. Proceedings of the 4. SMEs and Productivity Congress, 4, 187-198. Retrieved from http://www.iku.edu.tr/userfiles/kongre_kitabi_4.pdf

Lee, J. (2013). Directions for the Sustainable Development of Korean Small and Medium Sized Shipyards. The Asian Journal of Shipping and Logistics, 29(3), 335-360. http://dx.doi.org/10.1016/j.ajsl.2013.12.003

Lewin, A. Y., \& Morey, R. C. (1981). Measuring the Relative Efficiency and Output Potential of Public Sector Organizations: An Application of Data Envelopment Analysis. International Journal of Policy Analysis and Information Systems, 5(4), 267-285.

Önüt, S., \& Soner, S. (2007). Analysis of Energy Use and Efficiency in Turkish Manufacturing Sector SMEs. Energy Conversion and Management, 48(2), 384-394. http://dx.doi.org/10.1016/j.enconman.2006.07.009

Prusa, J. (2012). The Most Efficient Czech SME Sectors: An Application of Robust Data Envelopment Analysis. Czech Journal of Economics and Finance, 62(1), 44-65.

Public Disclosure Platform. (2015). Retrieved December 29, 2015 from http://www.kap.gov.tr/bildirim-sorgulari/bildirim-detayi.aspx ?id=317276

Ramathan, R. (2003). An Introduction to Data Envelopment Analysis: A Tool for Performance Measurement. New Delhi: Sage Publications.

Reverte, C., \& Guzman, I. (2010). The Predicitive Ability of Relative Efficiency for Future Earnings: An Application Using Data Envelopment Analysis to Spanish SMEs. Applied Economics, 42(21), 2751-2757. http://dx.doi.org/10.1080/00036840801964575

Shammari, M. (1999). Optimization Modeling for Estimating and Enhancing Relative Efficiency with Application to Industrial Companies. European Journal of Operational Research, 115(3), 488-496. http://dx.doi.org/10.1016/S0377-2217(98)00025-3

Stokes, J. R., Tozer, P. R., \& Hyde, J. (2007). Identifying Efficient Dairy Producers Using Data Envelopment Analysis. American Dairy Science Association, 90(5), 2555-2562. http://dx.doi.org/10.3168/jds.2006-596

Tangen, S. (2005). Demystifing Productivity and Performance. International Journal of Productivity and Performance Management, 54(1), 34-46. http://dx.doi.org/10.1108/17410400510571437

The Official Gazette. (2016). Retrieved January 21, 2016 from http://www.resmigazete.gov.tr/eskiler/2012/11/20121104-11.htm

Tofallis, C. (2001). Combining Two Approaches to Efficiency Assessment. The Journal of the Operational Research Society, 52(11), 1225-1231. http://dx.doi.org/10.1057/palgrave.jors.2601231 
TurkStat-Turkish Statistical Institute. (2016) $\quad$ Retrieved $\quad$ February $\quad 22, \quad 2015$ from http://www.tuik.gov.tr/PreHaberBultenleri.do?id=18521

Yang, J. (2006). The Efficiency of SMEs in the Global Market: Measuring the Korean Performance. Journal of Policy Modeling, 28(8), 861-876. http://dx.doi.org/10.1016/j.jpolmod.2006.07.004

Zhu, J. (2000). Multi-Factor Performance Measure Model with an Application to Fortune 500 Companies. European Journal of Operational Research, $123(1), \quad 124$. http://dx.doi.org/10.1016/S0377-2217(99)00096-X

\section{Copyrights}

Copyright for this article is retained by the author(s), with first publication rights granted to the journal.

This is an open-access article distributed under the terms and conditions of the Creative Commons Attribution license (http://creativecommons.org/licenses/by/3.0/). 